\title{
テクノロジーイノベーション
}

\section{||||||||||||||||||||||||||||||||||||||||||||||||||||||||||||||||||||||||||||||||||||||||||||||||||||||||| ジペプチド発酵技術の開発と工業化}

\section{田畑和彦}

協和発酵バイオ株式会社バイオプロセス開発センター

\section{1. はじめに}

弊社の前身（協和発酵工業）には珍しい「発醅工業」 という文言が入っていた。これは化学合成法を基盤とし た化学工業と等しく,「発酵」を物質の変換・製造方法 の基盤とする，当時では斬新な創業を意図したもので あった。 その意志は受け継がれ，その後に急速に発展し た分子生物学の助けもあり現在では発醳法を基盤とした 製造業のカテゴリーが認知されるようになった。しかし 旧来の「発酵」とは, 糖質から微生物の生命現象を介し てエタノールのようなアルコールまたは酢酸，乳酸のよ うな有機酸という限られた単純な化合物へ変換する術で あり, 太古より人類が経験して伝えられる食品加工の方 法である。これが単一化合物の合成を目的とした製造法 になりえたのは，大規模で微生物の純粋培養を可能にし た装置の技術革新が前提にあったのは当然だが，それに 加えてアミノ酸生産微生物の発見 ${ }^{(1)}$ とそれに起因したア ミノ酸発酵技術の確立によるところが大きい.

アミノ酸は細胞を構成する主要な代謝産物であり，そ れまでの常識では微生物が増殖中に過剩に生成・分泌す るとは考えられなかった。しかしながら当時先端の実験 手法を駆使して自然界より探索してみるとアミノ酸の一 種（グルタミン酸）を分泌生産する微生物（コリネ属細 菌：Corynebacterium glutamicum）が見いだされた。 またこの現象は限られた生育条件でしか見られず，その
メカニズムの解明を契機にして「代謝制御発酵」という 概念が酻成した。これは微生物の代謝を, 遺伝的・生化 学的な手法で人為的に改変・制御することにより目的と するさまざまな発酵生産物を大量に蓄積させるという考 え方である。この頃には細胞内で起きる多様な酵素反応 からなる，まさに地図のような代謝経路の概要を把握で きる状況にあり, 分子生物学の進展による遺伝子工学技 術の充実と相まって, 急速に発酵生産菌の育種研究とそ の能力開発が進展することとなった，それまでの生産対 象は, アミノ酸のような主要な細胞構成成分 (一次代謝 産物）と，属種によるが元来微生物が生産する抗生物質 などの二次代謝産物が中心であったが, 最近の急速な遺 伝子解析技術の発展によりヒトゲノムが全解明されるま でになり, 原核, 真核生物問わず膨大な遺伝子情報が蓄 積され，またこれまでの学術研究の成果からの機能情報 も上書きされて, それらの情報は代謝改変の視野を大き く広げる重要な要素として役立つことになった。

その結果, 現在の発醅製法開発のトレンドは, 微生物 が生合成できる化合物をより安く大量に作るという方向 から，化学合成法で効率化が難しい複雑な構造のもの や，(動・植物からの）抽出により微量でしか得られな い希少な化合物へ対象が移ってきている. それらは同時 に既知の酵素反応の組み合わせでは到底生合成が成立し ない,つまりは常識的には考えられない課題になる場合 もある。これら難題の解決に際して, 過去からの学術情 


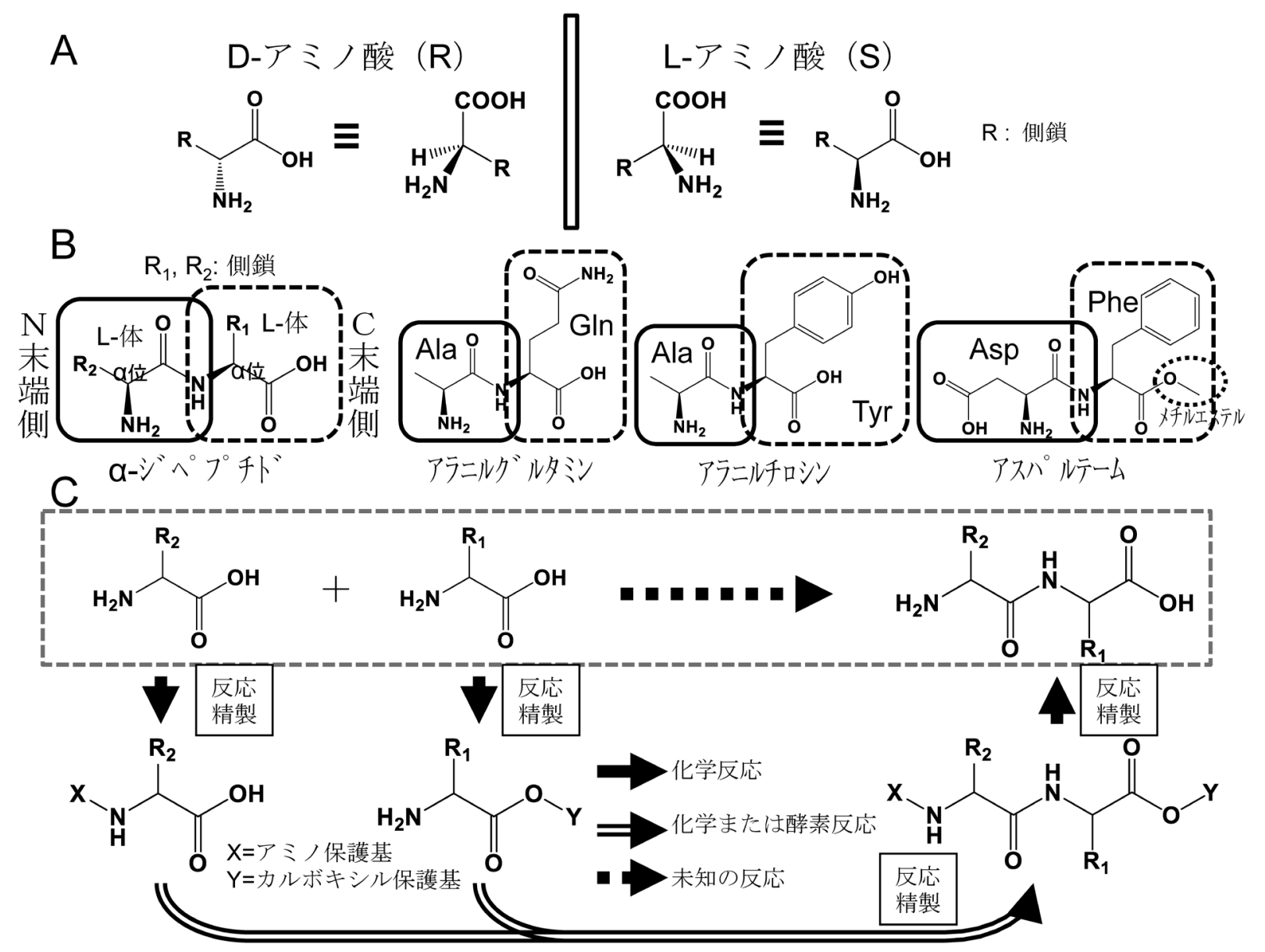

図 1 -アミノ酸の鏡像異性体 $\boldsymbol{\alpha}$-ジペプチドと各種ジペプチドの構造およびジペプチドの従来の製法（化学合成法）と理想の酵素反応 (破線部分)

報を網羅して現状を把握することはもちろん重要なこと だが，半面それまでに形成された常識に捕らわれない新 しい発想を生み出せることがより必要になってきてい る. 私を含め発酵技術の研究者の多くは農芸化学を学ん だ者が多い。目的達成への手法・手段へのこだわりが少 ない，逆にいえば何でも技術を取り入れようとする貪欲 な「農芸化学」の学問気質を学んだからこそ，また特に 私は良くも悪くも学術的常識が希薄であったからこそ, この話題をお伝えできるのかもしれない.また現在の発 酵工業が成立する礎となったアミノ酸発酵技術の革新 も, 当時の異端的発想でありながらも, 的確な科学的解 析が進められたからこそ導くことができた偉大な先例で あるといえよう。

\section{ジペプチドとは}

今回の対象とするジペプチドとは，細胞を構成する天 然型 $\mathrm{L}-ア ミ ノ$ 酸（図1A）同士が， $\alpha$-位でペプチド結合

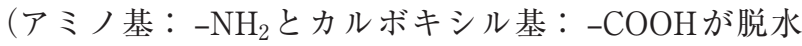

縮合を経て形成する結合のこと）を形成したものをいう (図 1B).

これが数十，数百と連なったものがペプチド，夕ンパ ク質であり細胞内構造体を形成している．最近ジペプチ ドという化合物を対象とした研究の中で，新たな物性や 生理活性を発現するという例が報告されている(2). それ らをまとめると主に以下の 2 種類に大別できる．1）構 成するアミノ酸の物理化学的性質を改善できること，2) 特定のジペプチド構造が，構成するアミノ酸の機能を超 えた新たな活性を発揮すること，1）については，アミ ノ酸の溶解度や安定性を向上させることであり，たとえ ばグルタミンというアミノ酸は水に対する溶解度が低い うえに，水に溶けても不安定（熱を加えるとで速やかに 分解する）なことから溶液としての製品化が不可能であ り用途が制限される特殊なアミノ酸である。しかしアラ ニンというアミノ酸と連結したアラニルグルタミン (AlaGln) というジペプチドにすることでその両方の欠 点は改善されることがわかっている．また同じく水に対 する溶解度がアミノ酸の中で最も低いため扱いにくかっ 


\begin{tabular}{lccc}
\hline \multicolumn{1}{c}{ アミノ酸 } & ジペプチド & 溶解性 $(\mathrm{g} / \mathrm{L})\left(\right.$ 水, $\left.25^{\circ} \mathrm{C}\right)$ & 溶液状態の熱安定性 \\
\hline グルタミン Gln & & 53.7 & 不安定 \\
& アラニルグルタミン AlaGln & 550 & 安定 \\
チロシンTy & & 0.62 & 安定 \\
& アラニルチロシン AlaTyr & 17.8 & 安定 \\
\hline
\end{tabular}

自社データ.

たチロシンでも同様の効果が確認されている（ジペプチ ドはアラニルチロシン（AlaTyr））（図1B, 表1)。2）の 代表例は，すでに商品化されている人工甘味料「アスパ ルテーム」である。これはアスパラギン酸とフェニルア ラニンが結合したジペプチドの誘導体（フェニルアラニ ンのカルボキシル基のメチルエステル体）であり（図 1B），これを構成するアスパラギン酸やフェニルアラニ ン自体に甘みは呈さないが，この特定ジペプチド（の誘 導体）の構造をなすことで砂糖の数百倍の甘みを発揮す ることが知られている.

このようにジペプチドの中には優れた機能の報告があ るものの, 商品化されたものは唯一「アスパルテーム」 であると言ってよいほど少ない，その主な原因は一般的 にジペプチドを製造するコストが高いことであった，従 来の製法は化学合成法であり，原料のアミノ酸自体は安 価だがペプチド結合を作るような官能基（アミノ基，力 ルボキシル基）を最低一つずつはもつため，特定の配列 (順番) で $\alpha$-位のペプチド結合を形成させるには，反応 しては困る部分にあらかじめ保護基を導入して反応する のを阻止させるという各構成するアミノ酸に適した複雑 な修飾工程が必要となる。つづいて目的の部位（保護基 の修飾のないアミノ基とカルボキシル基の間で）での縮 合によるぺプチド結合を形成させ，最後に保護基を外す という複数の工程からなる煩雑さが高コストの主要因で ある。 そこで従来の化学合成法の課題を解決するために 誰もが容易に考えつくのは，アミノ酸を酵素の働きで修 飾することなく目的の配列のみで結合させることである （酵素の基質特異性で特定構造を優先的に結合する）（図 1C)。しかしこのような活性の報告は今までになく，そ れゆえ新たにその活性を探し出すか, 既知酵素から作り 出す（酵素のアミノ酸配列を変えることで性質を改変す ること）必要があった。 そこで今回は物性改善の要望が 強いアミノ酸のグルタミンとチロシンに準ずるジペプチ ドである AlaGln と AlaTyrを具体的な目標とし，革新的 な新製法開発の第一歩として未知なるジペプチド合成䣲 素を探索することにした.

\section{新規ジペプチド合成酵素の探索と単離 ${ }^{(3)}$}

ジペプチドは，生化学的な解釈では細胞内に元々存在 するものと言われる，その合成メカニズムは，2つのア ミノ酸が連結して作られるのではない. 生命現象を維持 するために細胞内では頻繁にさまざまなタンパク質の合 成とその分解（プロテオリシス, proteolysis）が繰り返 されている。ジペプチドは，そのアミノ酸への分解過程 の中間体であり，それ自体に特定の生理機能はないもの と考えられてきた。ここでわれわれの最初の課題は，こ のような常識を覆してジペプチドさらには AlaGln およ びAlaTyrの構造を優先的に合成する酵素活性を探し出 すということになった。ここで注意すべきは微生物を含 めたすべての細胞には，プロテオリシスの正体である強 いペプチド結合分解活性つまりジペプチドも容易に分解 する生物共通の特性が存在していることである。

通常新たな醳素活性を探索する場合，自然界からさま ざまな生物種（細菌, 酵母, カビなど）を単離し，簡単 に準備できるそれら細胞の抽出液を酵素源として新たな 活性評価が行われる。しかし今回の対象であるジペプチ ドにこの方法は適さないことは容易に想像できた。それ は仮に目的活性があり微量のジペプチドが合成されたと しても, 細胞由来の分解活性により速やかに分解・相殺 され感度良く検出することはできないからだ。そこでこ の問題点を解決する方法として，あらかじめ大腸菌を利 用して組換え型酵素を作らせ精製した酵素標品を用いて 活性評価することを考えた。このひと手間で細胞成分由 来の分解活性を排除した状態で評価することが可能にな る。しかしこの煩雑になった評価方法を効率的に進める ための必要条件として, 評価候補となる醅素群について 発見できるだけの十分な質と量の遺伝子配列情報が必要 となる（組換え型酵素を作製するのに必須の情報）。幸 い膨大に解析が進む遺伝子配列情報は共有化され，また クエリー (手持ちのアミノ酸配列) があればプログラム に従いそれに対する相同性（共通の先祖や機能を有する 度合い）の序列を公開されるデー夕から机上で簡単に網 羅的に解析できる. 
A<smiles>CC(N)C(=O)O</smiles>

B
D-Ala
D-Ala

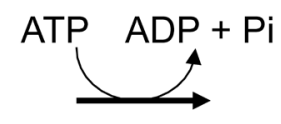

Ddl<smiles>CC(N)C(=O)NC(C)C(=O)O</smiles>

D-アランシンーD-アラランンリガーゼ

[EC 6.3.2.4]

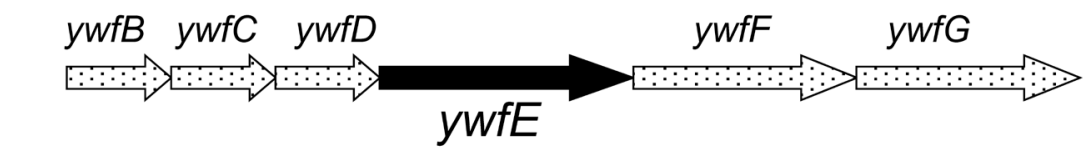

C<smiles>CC(N)C(=O)O</smiles><smiles>N[C@@H](C[C@H]1O[C@@H]2C(=O)CC[C@H]21)C(=O)O</smiles><smiles>CC1CC1</smiles><smiles>CC(N)C(=O)NC(C[C@H]1CCC(=O)[C@H]2O[C@H]21)C(=O)O</smiles>

D<smiles>CC(N)C(=O)O</smiles>

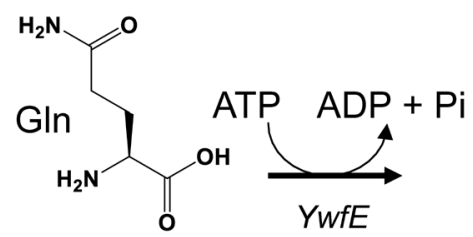

L-アミノ酸 $\alpha$-リガーゼ (Lal)<smiles>CC(N)C(=O)NC(CCC(N)=O)C(=O)O</smiles>

[EC 6.3.2.28]

図 2 『 $\mathrm{D}$-アラニン-D-アラニンリガーゼの酵 素反応, 枯草菌のバシリシン生合成クラス ターと推定合成反応，および実際のL-アミ ノ酸 $\alpha$-リガーゼの酵素反応

表2匹YwfEが合成可能なジペプチド

\begin{tabular}{|c|c|c|c|c|c|c|c|c|c|c|c|c|c|c|c|c|}
\hline & & \multicolumn{15}{|c|}{ C 末側 L-アミノ酸 } \\
\hline & & Gly & Ala & Ser & Cys & Thr & Val & Leu & Ile & Met & Phe & Tyr & $\operatorname{Trp}$ & Gln & Asn & His \\
\hline N末側 L-アミノ酸 & $\begin{array}{l}\text { Gly } \\
\text { Ala } \\
\text { Ser } \\
\text { Thr } \\
\text { Met } \\
\text { Cys }\end{array}$ & $\begin{array}{l}0 \\
0 \\
0 \\
0\end{array}$ & 0 & 0 & $\begin{array}{l}0 \\
0 \\
0\end{array}$ & $\begin{array}{l}0 \\
0 \\
0\end{array}$ & 0 & $\begin{array}{l}0 \\
0 \\
0 \\
0\end{array}$ & $\begin{array}{l}0 \\
0 \\
0\end{array}$ & $\begin{array}{l}0 \\
0 \\
0 \\
0 \\
0 \\
0 \\
0\end{array}$ & $\begin{array}{l}0 \\
0 \\
0 \\
0 \\
0 \\
0\end{array}$ & $\begin{array}{l}0 \\
0 \\
0\end{array}$ & ? & $\begin{array}{l}0 \\
0 \\
0\end{array}$ & 0 & $\begin{array}{l}0 \\
0 \\
0 \\
0\end{array}$ \\
\hline
\end{tabular}

縦 : 生成するジペプチドの $\mathrm{N}$ 末端側になりえるアミノ酸, 横: 生成するジペプチドのC末端側になりえるアミノ酸, ○で示すジペプチドの 生成が確認された。

しかし今回は活性の存在の確証すらない未知の酵素活 性であることから，検索の鍵となるクエリーがない状態 でのスタートとなった。そこでまず，これまで報告され るペプチド結合形成酵について整理したところ，すべ てに共通する性質としてATPに依存した䤉素反応であ ることがわかった，ゆえに未知なるジペプチド合成酵素 の反応も同じ性質であるという仮説を立て，また既知酵 素の中で最も似た反応をする酵素として D-アラニン-D-ア ラニンリガーゼ（Ddl）（細菌由来の細胞壁構成成分で あるD-アラニン同士からなる $\alpha$-ジペプチドの合成酵素, 図2A）に着目した。ここで実在する醰素の配列情報が 得られたわけだが，これをクエリー配列として相同性解 析を行っても既知のさまざまな細菌由来の機能が推定さ れるDdlに占められるだけの結果で意味がなかった。そ こでDdlも有するATP依存反応で共通して保存される
酵素の一部を構成する特徵的構造; ATP-grasp ドメイ ン (4)に注目することにした。そして実際の候補酵素遺伝 子の机上での選抜は，まずゲノムデータベースを使って ATP-grasp ドメインに対する相同性解析の序列化デー 夕得て，その上位のものから Ddlに対する相同性と同時 に対象が未だ報告のない新たな活性であることから機能 が未特定と登録される遺伝子に絞って手作業で選別を 行った。

その結果, 全ゲノム情報が解明された枯草菌の $Y w f E$ という遺伝子がその最上位の候補に該当することがわ かった。この遺伝子は，ジペプチド類似構造の抗生物質 であるバシリシンの生合成にかかわるという報告 ${ }^{(5)}$ が あったが，この遺伝子産物自体の役割は不明であった (図2B，C)。そこで計画どおりに大腸菌にて組換え型酵 素を発現させ，精製した酵素を取得した。本来ならばバ 
シリシンを構成するアラニンとアンチカプシンという特 殊な化合物を用いて反応を評価すべきであるが，後者が 入手できなかったので，われわれの目的とする AlaGln の生合成で評価することとした，アラニン，グルタミン およびATPを加えて反応させたところ，幸いにして AlaGlnの生成が確認できた (図 $2 \mathrm{C}, \mathrm{D})$. これはアンチ カプシンがグルタミンの阻害剂（グルタミンと構造が似 ていて, 誤って酵素が利用することによる活性発現の阻 止物質）としての機能で抗菌活性を示すこと ${ }^{\left({ }^{6}\right)}$ からも納 得できる結果であった。つづいて 20 種類ある天然型ア ミノ酸を組み合わせて網羅的にジペプチドの生成を評価 したところ，さまざまな配列のジペプチドができること がわかった（表2）。この結果は，一般的な酵素の基質 特異性の常識からすれば想定外であった。また幸いにし て対象とする AlaGln およびAlaTyrに対する反応性は比 較して高いものであった。

性質をまとめると, L-体のアミノ酸しか反応しない, ジペプチドより長いペプチドは合成しない， $\mathrm{N}$ 末端側の アミノ酸は側鎖の小さなアミノ酸 (グリシン, アラニン, セリンなど), C末端側のアミノ酸は極性がなくかさ張る 側鎖のアミノ酸 (芳香族, 分岐鎖, メチオニン, グル夕 ミンなど）の特異性が高いことがわかった。この全く新 しい活性を有する酵素のことを「L-アミノ酸 $\alpha$ リリガーゼ (L-amino acid $\alpha$-ligase; Lal) 䤃素番号 [EC 6.3.2.28]」と 名づけることにした（図2D）。そしてこの酵素は後に結 晶構造解析が行われ, その詳細な反応機構も解明されて きている(7), また YwfEの発見によりその相同性解析か ら同様の活性を示す䤉素が同定され一群のグループを形 成することがわかってきている( ${ }^{(8)}$.. それらのアミノ酸 に対する基質特異性にも多様性が認められ，Lalにより 合成できるジペプチドの種類も拡大することになった.

\section{ジペプチド発酵技術の開発と工業化 ${ }^{(10)}$}

最初の検討課題であったアミノ酸からジペプチドを直 接結合する酵素は単離・同定できた。この酵素活性を最 も効果的に活かせる生産プロセスとして「発酶法」を選 んだ。発酵法は糖質を主な原料として生産菌株を培養す ることで糖質を消費し, 細胞が増殖する間に目的産物を 過剩に生合成しその多くを細胞外（培地中） 一蓄積させ ることであり，化学合成法で問題となる産物の合成工程 を細胞内の酵素反応で完結できることから極めて簡便に できる製法であると言える. Lalの活性発現には基質と して構成するアミノ酸抢よびATPを与え続けることが できればジペプチドを継続して効率的に生産できると考

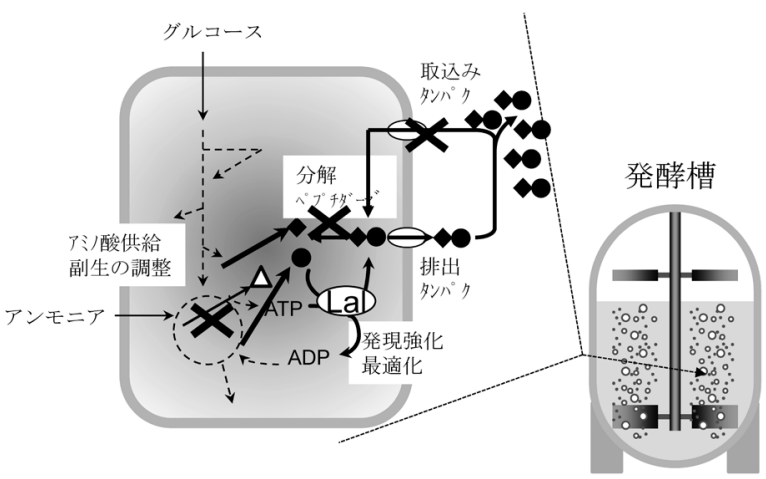

図3ロジペプチド発酵製法の概要

えられる。そこで，これまで培ってきた「アミノ酸発 䣲」の知見（細胞はアミノ酸を自前で糖を原料に生合成 できることと同時に，生育中にATPも生成すること） に従い，生きた微生物細胞において Lal 活性を組み合わ せることができればジペプチドの発酵生産が容易にでき ると考えられた。そこで大腸菌野生株でプラスミドを用 いて Lalの発現強化した株を作製し培養してみたが，予 想を反してジペプチドの生成は確認できなかった.

そこでジペプチドを発酵生産できる条件検討を行っ た。その結果，以下に示す3つの必要条件（図3）を解 明した. [1] Lalを適度な強さで安定に発現させること （過剩な場合は生育を阻害し不足の場合は生合成しなく なるので), [2] 宿主細胞のもつジペプチド分解活性を 弱化させること（大腸菌の場合は分解にかかわるぺプチ ダーゼ遺伝子群が特定でき, 染色体上の遺伝子破壊を施 した)，［3］目的となるジペプチドを構成するアミノ酸 の供給能力を強める（従来のアミノ酸発酵における生産 菌株育種の知見を利用する, AlaGlnの場合はアラニン とグルタミン (11)).

そして実験室におけるジペプチド発醉製法のプロト夕 イプを確立できたので，つづいて工場にある実設備での 操業を目標とするスケールアップ検討に移ることになっ た，その際に，目的ジペプチドと配列の異なる副生ジペ プチドが著量蓄積するというこれまでなかった課題が認 められた。この副生ジペプチドは目的産物と極めて近似 した物性を示すため, 発酵後の単離・晶析工程での分離 除去は困難であることがわかった，そこで発酵中におけ る副生ジペプチドの生成低減検討を取り組んだ。前述の $\mathrm{Lal}$ の性質から元々さまざまなアミノ酸の組み合わせか らいろいろなジペプチドを合成できることがわかってい る。このことは多種類のジペプチドの合成へ利用できる 可能性を示す半面, 単一種のみを生産する場合にはデメ リットになる性質であると言える，生産菌の細胞内で は，育種によって特定アミノ酸の生合成を強化して細胞 
内の濃度を高めているものの，それ以外のアミノ酸につ いても（育種をしなくても）多少の量は存在しており， また培養条件が変わればその代謝の変動も予想される. そして今回はスケールアップにより結果的に副生ジペプ チドを構成するアミノ酸の細胞内濃度の増加を招いたこ とが原因であると考えられた。そこで問題となるアミノ 酸の生合成に関して，遺伝子組換え技術で弱化させる育 種を施したところ副生低減効果を確認することができ た。またほかの考え方として，目的ジペプチドを選択的 に細胞外へ排出することができれば，生産性と同時に産 物純度も向上できると考えられた，そこで大腸菌の内在 性薬剂排出タンパク質（膜結合型タンパク質で, 各種薬 凨, 抗生物質, 毒物を能動的に排出して細胞に耐性能力 を与えるもの）とされるものを中心に評価し，対象の AlaGlnに特性を示す排出タンパク質を同定できた ${ }^{(12)}$. 最終的な株はこの 2 通りの育種を組み合わせることで, 工業スケールにおいても高効率で，しかも高純度でジペ プチドを生産できる発䣲プロセスに完成させることがで きた（図3）。つづく培養液からのジペプチドの単離・ 晶析工程については, 従来のアミノ酸発酵におけるその 技術を踏襲し最適化することで，新たに特別な操作・装 置を用いることなく低コストで高収率に製品化が可能な ことが確認された．現在，このプロセスは国内工場（弊 社・山口事業所）で実施している.

\section{おわりに}

これまでにジペプチドという化合物において有用な機 能が報告され, 新素材候補として大きな可能性が示され てきている。しかしながら一般的にその製造コストが高 いことから，一部の例外を除き製品化は抢ろか機能評価 も不十分な状態にあった。今回われわれは従来製法の問 題点を根本的に解決すべく，それまでの酵素学的常識に 反した発想から新たな活性を探索し，それを見つけ出し て同定し，その新規活性を最大限に活かすべく発酵製法 へ組み込んで全く新しい効率的なプロセスにすることが できた。このことを過去のアミノ酸における製法革新と それに伴う市場の変遷に重ねて見てみたい。 その昔アミ ノ酸は希少品で用途も制限されていたが，䩢的な「発 酵法」の確立により生産効率の飛躍的向上と同時に製造 コストが低減され，さまざまな需要が喚起され今では身 近な製品に用いられる汎用素材として巨大な市場を形成 している。それに呼応して現在ではほとんどの種類のア ミノ酸の製造方法が発醳法に切り替わっている。このジ ペプチド発酵製法も，ジペプチドという素材の需要を喚
起させる起爆剂になることを期待している。 その先例と して今回はAlaGln およびAlaTyrを従来製法の製造コス トの $1 / 10$ 以下で供給できることを示せた．前者は医療 用輸液への添加や, 米国においては健康食品素材とし て, また後者も含めバイオ医薬品製造で重要な動物細胞 培養に打ける培地成分として開発を進めている。アミノ 酸は 20 種類に限られるが，ジペプチドはその配列（組 合せ）により 400 種類もの多種類にわたる製品群を形成 する。それゆえ未開拓のものは多く，今回の製法を利用 することで評価用の標品取得や商業生産などで役立つこ とと, 付随する機能研究の効率化によりジペプチドが過 去のアミノ酸の経緯を再現するような大きな市場へ発展 することを期待している.

\section{文献}

1) S. Udaka: J. Bacteriol., 79, 754 (1960).

2) M. Yagasaki \& S. Hashimoto: Appl. Microbiol. Biotechnol., 81, 13 (2008).

3) K. Tabata, H. Ikeda \& S. Hashimoto: J. Bacteriol., 187, 5195 (2005)

4) L. M. Iyer, S. Abhiman, A. Maxwell Burroughs \& L. Aravind: Mol. Biosyst., 5, 1636 (2009).

5) T. Inaoka, K. Takahashi, M. Ohnishi-Kameyama, M. Yoshida \& K. Ochi: J. Biol. Chem., 278, 2169 (2003).

6) H. Chmara: J. Gen. Microbiol., 131, 265 (1985).

7) Y. Shomura, E. Hinokuchi, H. Ikeda, A. Senoo, Y. Takahashi, J. Saito, H. Komori, N. Shibata, Y. Yonetani \& Y. Higuchi: Protein Sci., 21, 707 (2012).

8) Y. Hamano, T. Arai, M. Ashiuchi \& K. Kino: Nat. Prod. Rep., 30, 1087 (2013).

9) 木野邦器: YAKUGAKU ZASSHI, 130, 1463 (2010)

10) K. Tabata \& S. Hashimoto: Appl. Environ. Microbiol., 73, 6378 (2007).

11) M. Hayashi \& K. Tabata: Appl. Environ. Microbiol., 79, 3033 (2013).

12) M. Hayashi, K. Tabata, M. Yagasaki \& Y. Yonetani: FEMS Microbiol. Lett., 304, 12 (2010).

\section{プロフィル}

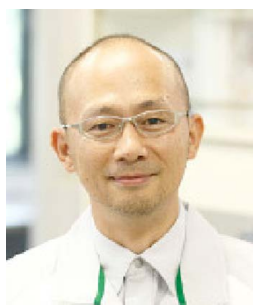

田畑 和彦 (Kazuhiko TABATA)

<略歴 $>1994$ 年名古屋大学農学部農芸化 学科卒業/1996年同大学大学院農学研究 科修士課程修了/同年協和発酵工業株式会 社, 東京研究所研究員 $/ 2005$ 年農学博士 取得 (東京大学) $/ 2008$ 年協和発酵バイオ 株式会社バイオプロセス開発センター研究 員 $/ 2009$ 年同主任研究員 / 2015 年同セン ター長, 現在に至る<趣味 $>$ 昼寝と散歩と 吞むこと<所属研究室ホームページ> http://www.kyowahakko-bio.co.jp/rd/interview/002/

Copyright (C) 2015 公益社団法人日本農芸化学会 DOI: 10.1271/kagakutoseibutsu.53.547 